УДК $582.734 .4+581.133$

\title{
ДИНАМИКА НАКОПЛЕНИЯ ФЕНОЛЬНЫХ СОЕДИНЕНИЙ В ОРГАНАХ САБЕЛЬНИКА БОЛОТНОГО (СОMARUM PALUSTRE L.)
}

\author{
() П.И. Петрова ${ }^{1}$, Е.Ю. Бахтенко ${ }^{*}$, Н.В. Загоскина ${ }^{2}$ С.В. Булатова ${ }^{1}$,.Б. Курапов ${ }^{1}$ \\ ${ }^{1}$ Вологодский государственный педагогический университет, ул. Орлова, 6, \\ Вологда, 160035 (Россия), e-mail: bakhtenko@yandex.ru \\ ${ }^{2}$ Институт фризиологии растений им. К.А. Тимирязева РАН, \\ ул. Ботаническая, 35, Москва, 127276 (Россия), e-mail: ofr@ippras.ru
}

\begin{abstract}
Изучена сезонная динамика накопления фенольных соединений в органах сабельника. Установлено, что наибольшее содержание растворимых фенольных соединений и флаванов наблюдается в надземных органах в фазе вегетации и цветения (июнь - июль), в корневищах - в фазу плодоношения (август). Растения сабельника генеративного возрастного состояния накапливают больше фенолов по сравнению с растениями виргинильного возрастного состояния. Содержание фенольных соединений зависит от климатических условий и достигает наибольших значений в более холодный и засушливый периоды.

Ключевые слова: Comarum palustre (L.), фенольные соединения, флаваны.
\end{abstract}

\section{Введение}

Сабельник болотный (Comarum palustre L.) - многолетнее травянистое растение или полукустарничек семейства Rosaceae. Растение является лекарственным и широко применяется в народной, а с недавнего времени официальной медицине многих стран. Установлены ранозаживляющее, противовоспалительное, иммуностимулирующее, антиревматоидное, болеутоляющее и противоопухолевое действия препаратов сабельника $[1,2]$.

Исследования химического состава сабельника немногочисленны. В растении обнаружены эфирные масла, пектиновые вещества, витамины, фенольные соединения, сапонины, терпеноиды, полисахариды [36]. Преобладающей группой веществ в растительном сырье сабельника являются фенольные соединения, представленные фенолкарбоновыми кислотами, флавоноидами (флавонолы, флавононолы, флавоны, флаваны, флаваноны), дубильными веществами [2, 4, 5].

Образование и накопление фенольных соединений изменяется в онтогенезе растения, зависит от факторов окружающей среды и распределения по тканям [7, 8]. Для разработки технологии рационального

Петрова Полина Ивановна - магистрант, e-mail: borisova-polina@mail.ru

Бахтенко Елена Юрьевна - первый проректор, доктор биологических наук, тел./факс: (8172) 76-91-96, e-mail: bakhtenko@yandex.ru

Загоскина Наталья Викторовна - профессор, доктор биологических наук, e-mail: ofr@ippras.ru

Булатова Светлана Викторовна - аспирант, e-mail: vavilon@vologda.ru

Курапов Павел Борисович - профессор, доктор биологических наук, тел./факс: (8172) 76-91-96, e-mail: bakhtenko@yandex.ru использования ресурсов лекарственного растения необходимо выявить период максимального накопления фенольных соединений, а также органа с высоким их содержанием, что позволит выработать практические рекомендации по оптимальным срокам сбора сырья. Изучение динамики накопления фенольных соединений является важным для определения биохимической функции фенолов и выяснения влияния условий на образование вторичных метаболитов в растениях.

\footnotetext{
* Автор, с которым следует вести переписку.
} 
Цель настоящей работы - изучение динамики накопления фенольных соединений в надземных и подземных органах сабельника болотного в зависимости от фазы развития, возрастного состояния и климатических условий.

\section{Экспериментальная часть}

Заготовка растительного сырья проводилась в 2006-2009 гг. в Кадуйском районе Вологодской области на переходном болоте (сфагново-осоково-сабельниковая ассоциация) в различные фазы вегетации (отрастание, вегетация, цветение, плодоношение, увядание). В работе изучались растения разных возрастных групп: виргинильное возрастное состояние (V-состояние), генеративное возрастное состояние (G-состояние), собранные в фазу плодоношения.

Собранное растительное сырье фиксировали методом воздушной сушки на открытом воздухе в тени. Определение содержания растворимых фенольных соединений осуществляли спектрофотометрическим методом. Для этого сухой материал подвергали трехкратной экстракции горячим 70\% этанолом [9]. Суммарное содержание растворимых фенольных соединений определяли с реактивом Фолина - Дениса (поглощение при 725 нм), флаванов - с раствором ванилина в 70\% серной кислоте (поглощение при 500 нм). Калибровочные кривые в обоих случаях строили по эпикатехину [9].

Биохимические исследования осуществляли на базе лаборатории липидного и фенольного метаболизма Института физиологии растений им. К.А. Тимирязева, а также в лаборатории физиологии растений Вологодского государственного педагогического университета.

Исследования проводились в трех биологических и трех аналитических повторностях. Все результаты обработаны статистически, на графиках и в таблицах представлены средние арифметические значения и их стандартные отклонения.

\section{Обсужнение результатов}

В результате проведенных исследований установлены различия в содержании растворимых фенольных соединений и флаванов в органах сабельника болотного. В фазу плодоношения в корневищах содержится больше фенольных соединений и флаванов по сравнению с надземными органами (табл. 1). В надземных органах сабельника фенольные соединения распределяются достаточно равномерно в листьях, стеблях и плодах. Флаванов обнаружено больше в стеблях, чем в листьях и плодах.

Для выяснения динамики накопления фенольных соединений анализировали содержание их общей суммы и суммы флаванов по фазам развития. Количество фенольных соединений в течение периода вегетации значительно изменяется: в надземной части растений - от 58 до 108, в подземной части - от 40 до 148 мг/г сухой массы (табл. 2).

Содержание фенольных соединений в надземной части сабельника болотного возрастает от фазы отрастания, достигая максимума к фазе вегетации и цветения и снижаясь к фазе плодоношения (табл. 2). Такая динамика фенольных соединений в надземных органах совпадает с периодами их наибольшего роста, что свидетельствует об участии фенолов в ростовых процессах и формировании репродуктивных органов $[8,10,11]$. Снижение количества фенольных соединений после цветения может быть связано с угасанием биосинтеза фенолов или с расщеплением их на отдельные фрагменты [7]. В литературе также отмечается способность фенольных соединений к оттоку в виде гликозидов в подземные органы [7]. Возможность перераспределения пула фенольных соединений между надземными и подземными органами подтверждается полученными данными по динамике фенольных соединений в подземной части растения.

Наибольшее количество фенольных соединений в корневищах накапливается к фазе плодоношения, а в конце вегетации при увядании надземной части снижается (табл. 2).

Таблица 1. Суммарное содержание растворимых фенольных соединений и флаванов в органах сабельника болотного, мг/г сухой массы

\begin{tabular}{c|c|c}
\hline Органы растения & Растворимые фенольные соединения & Флаваны \\
\hline Лист & $43,41 \pm 1,35$ & $6,31 \pm 0,69$ \\
Стебель & $40,62 \pm 1,99$ & $21,71 \pm 2,86$ \\
Плоды & $39,47 \pm 1,79$ & $9,47 \pm 1,35$ \\
Корневище & $147,89 \pm 17,04$ & $102,27 \pm 21,54$ \\
\hline
\end{tabular}


Таблица 2. Суммарное содержание растворимых фенольных соединений и флаванов в сабельнике болотном в фазы вегетации, мг/г сухой массы

\begin{tabular}{c|c|c|c|c}
\hline \multirow{2}{*}{ Фенофаза } & \multicolumn{2}{|c|}{ Растворимые фенольные соединения } & \multicolumn{2}{|c}{ Флаваны } \\
\cline { 2 - 5 } & Надземная часть & Подземная часть & Надземная часть & Подземная часть \\
\hline Отрастание & $58,97 \pm 1,39$ & $40,95 \pm 1,50$ & $5,26 \pm 0,32$ & $80,27 \pm 2,68$ \\
Вегетация & $108,10 \pm 12,54$ & $45,05 \pm 1,25$ & $30,60 \pm 2,68$ & $80,27 \pm 1,76$ \\
Цветение & $107,45 \pm 16,61$ & $107,45 \pm 9,25$ & $21,45 \pm 0,76$ & $90,34 \pm 5,87$ \\
Плодоношение & $64,58 \pm 3,13$ & $147,89 \pm 6,38$ & $5,64 \pm 0,27$ & $102,27 \pm 12,54$ \\
Увядание & - & $84,35 \pm 1,65$ & - & $68,43 \pm 3,05$ \\
\hline
\end{tabular}

Содержание флаванов в надземных и подземных органах изменяется аналогично общему содержанию фенольных соединений с максимумом в надземных органах в фазу вегетации, а в подземных - в фазу плодоношения (табл. 2).

На рисунке представлены данные по содержанию растворимых фенольных соединений за разные годы исследований. На фоне сходной общей динамики показатели конкретных вегетационных периодов двух лет различаются, что связано с отличиями климатических условий. В целом лето 2007 г. характеризовалось более низкой среднемесячной температурой и небольшим количеством осадков по сравнению с летом 2008 г. Вместе с тем имеются различия в погодных условиях первых месяцев лета: июнь 2008 г. а отличался пониженными температурами и отсутствием осадков по сравнению с июнем 2007 г. Сопоставление данных позволяет судить, что концентрация фенольных соединений выше в растениях сабельника, собранных в более холодный и засушливый периоды. Это подтверждает мнение о фенольных соединениях как стрессовых метаболитах, накапливающихся при менее благоприятных климатических условиях.

При анализе сабельника болотного разных возрастных состояний, собранных в фазу плодоношения, выявлено, что в растительном сырье генеративного возрастного состояния содержалось больше фенольных соединений по сравнению с растениями виргинильного возрастного состояния (табл. 3). В надземных органах сабельника генеративного и виргинильного возрастных состояний обнаруживалось приблизительно одинаковое количество флаванов, в подземных органах их содержание выше у растений генеративного возрастного состояния (табл. 3).

Таблица 3. Суммарное содержание фенольных соединений и флаванов в зависимости от возрастного состояния, мг/г сухой массы

\begin{tabular}{c|c|c|c|c}
\hline \multirow{2}{*}{$\begin{array}{c}\text { Возрастное } \\
\text { состояние }\end{array}$} & \multicolumn{2}{|c|}{ Растворимые фенольные соединения } & \multicolumn{2}{|c}{ Флаваны } \\
\cline { 2 - 5 } & Надземная часть & Подземная часть & Надземная часть & Подземная часть \\
\hline Генеративное & $64,58 \pm 6,00$ & $147,89 \pm 14,43$ & $5,64 \pm 0,27$ & $102,27 \pm 9,54$ \\
Виргинильное & $40,62 \pm 1,14$ & $76,98 \pm 6,56$ & $6,31 \pm 0,41$ & $62,51 \pm 2,02$ \\
\hline
\end{tabular}

A



Б

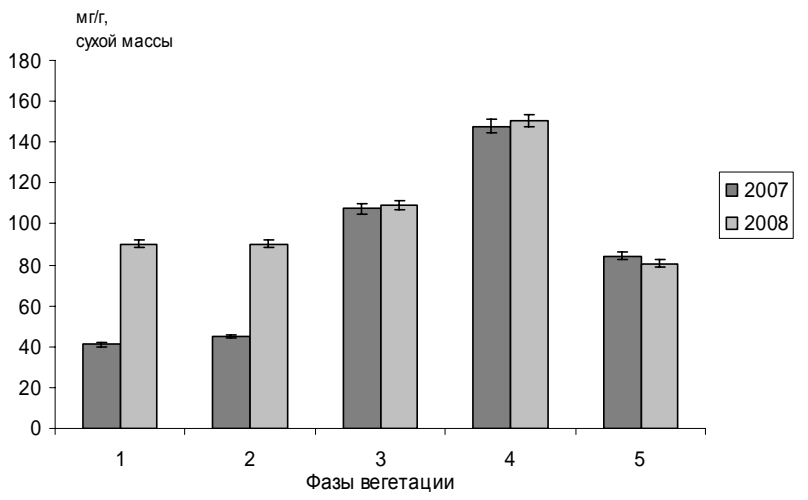

Рис. 1. Сумма растворимых фенольных соединений в надземной (А) и подземной (Б) частях сабельника болотного в фазы вегетации: 1 - отрастание; 2 - вегетация; 3 - цветение; 4 - плодоношение; 5 - увядание 


\section{Выводы}

Интенсивность накопления фенольных соединений зависит от периода развития, органа растения, возрастного состояния и климатических условий лет наблюдений.

В более холодный и засушливый периоды в растениях сабельника накапливается больше растворимых фенольных соединений.

Наибольшее количество фенольных соединений (общая сумма, флаваны) в надземных органах отмечается в фазу вегетации и цветения, в подземных органах - в фазу плодоношения. Установлены различия в накоплении фенольных соединений в органах сабельника болотного. В фазу плодоношения в корневищах содержится больше растворимых фенольных соединений и флаванов по сравнению с надземными органами.

Количество фенольных соединений выше в растениях генеративного возрастного состояния.

Таким образом, в качестве лекарственного растительного сырья сабельника болотного целесообразно использовать надземные органы генеративного возрастного состояния в фазу вегетации, подземные органы - в фазу плодоношения. Также целесообразна заготовка растений в фазу цветения, когда характерно высокое содержание фенольных соединений для надземных органов и корневищ.

\section{Сиисок литературь}

1. Гаммерман А.Ф., Кадаев Г.Н., Яценко-Хмелевский А.А. Лекарственные растения (растения-целители). М., 1990. $207 \mathrm{c}$.

2. Чемесова Н.И., Чижиков Д.В. Определение содержания дубильных веществ в корневищах Comarum palustre L. и настойки из него спектрофотометрическим методом // Растительные ресурсы. 2004. Вып. 3. С. 122-129.

3. Наумчик Г. Н., Розенцвейг Г. Е. Исследование эфирного масла сабельника болотного // Аптечное дело. 1963. Т. 12, №5. C. 24-27.

4. Жукова О.Л. Фитохимическое изучение сабельника болотного, сухого экстракта на его основе и их стандартизация : автореф. дис. ... канд. биол. наук. М., 2007. 21 с.

5. Малюк Е.В. Фармакогностическое изучение травы сабельника болотного : автореф. дис. ... канд. фарм. наук. Пятигорск, 2007. 24 с.

6. Ковалев И.П., Литвиненко В.И. Исследование флавоноидных гликозидов. Моногликозиды // Химия природных соединений. 1965. №4. С. 233-241.

7. Запрометов М.Н. Фенольные соединения: распространение, метаболизм и функции в растениях. М., 1993. 272 с.

8. Ломбоева С.С., Танхаева Л.М., Оленников Д.Н. Динамика накопления флавоноидов в надземной части ортилии однобокой (Orthilia Secunda (L.) House) // Химия растительного сырья. 2008. №3. C. 83-88.

9. Запрометов М.Н. Основы биохимии фенольных соединений: учебное пособие. М., 1974. 214 с.

10. Высочина Г.И. Динамика содержания и компонентного состава флавоноидов Polygonum aviculare L. // Растительные ресурсы. 1999. Вып. 3. С. 67-74.

11. Артемкина Н.А., Рощин В.И. Экстрактивные вещества хвои и побегов Picea abies (Pinaceae). 3. Динамика содержания фенольных соединений // Растительные ресурсы. 2006. Вып. 3. С. 66-73.

Поступило в редакичию 27 февраля 2012 2.

После переработки 22 июля 2012 г.

Petrova P.I. ${ }^{l}$, Bahtenko E.J. ${ }^{I^{*}}$, Zagoskina N.V. ${ }^{2}$, Bulatova S.V. ${ }^{1}$, Kurapov P.B. ${ }^{l}$ DYNAMICS OF ACCUMULATION OF PHENOLIC CONNECTIONS IN BODIES COMARUM PALUSTRE L.

${ }^{1}$ Vologodsky State Pedagogical University, Orlova st., 6, Vologda, 160035 (Russia), e-mail: bakhtenko@yandex.ru

${ }^{2}$ Institute of Plant Physiology K.A. Timiryazev RAS, Botanicheskaia st., 35, Moscow, 127276 (Russia),

e-mail: ofr@ippras.ru

Seasonal dynamics of phenolic connections accumulation in the bodies is studied. It is established that the greatest content of soluble phenolic connections and phlavans is observed in elevated bodies in a vegetation and flowering phase (JuneJuly), in rhizomes - in a fruiting phase (August). The Comarum palustre plants of a generative age condition accumulate more phenols in comparison with the plants of vegetative age condition. The content of phenolic connections depends on environmental conditions and reaches the greatest values during colder and droughty period.

Keywords: Comarum palustre (L.), phenolic connections, phlavans.

\footnotetext{
* Corresponding author.
} 


\section{References}

1. Gammerman A.F., Kadaev G.N., Iatsenko-Khmelevskii A.A. Lekarstvennye rasteniia (rasteniia-tseliteli). [Medicinal plants (plants healers)]. Moscow, 1990. 207 p. (in Russ.).

2. Chemesova N.I., Chizhikov D.V. Rastitel'nye resursy, 2004, no. 3, pp. 122-129. (in Russ.).

3. Naumchik G.N., Rozentsveig G.E. Aptechnoe delo, 1963, vol. 12, no. 5, pp. 24-27. (in Russ.).

4. Zhukova O.L. Fitokhimicheskoe izuchenie sabel'nika bolotnogo, sukhogo ekstrakta na ego osnove i ikh standartizatsiia : avtoref. dis. ... kand. biol. nauk. [Phytochemical study of marsh cinquefoil, dry extract on its base and standardization: summary Ph.D. dissertation biol. Science.]. Moscow, 2007, 21 p. (in Russ.).

5. Maliuk E.V. Farmakognosticheskoe izuchenie travy sabel'nika bolotnogo : avtoref. dis. ... kand. farm. nauk. [Pharmacognostic study grass marsh cinquefoil: summary Ph.D. dissertation Pharm. Science.]. Piatigorsk, 2007,24 p. (in Russ.).

6. Kovalev I.P., Litvinenko V.I. Khimiia prirodnykh soedinenii, 1965, no. 4, pp. 233-241. (in Russ.).

7. Zaprometov M.N. Fenol'nye soedineniia: rasprostranenie, metabolizm i funktsii v rasteniiakh. [Phenolic compounds: distribution, metabolism and function in plants]. Moscow, 1993, 272 p. (in Russ.).

8. Lomboeva S.S., Tankhaeva L.M., Olennikov D.N. Khimiia rastitel'nogo syr'ia, 2008, no. 3, pp. 83-88. (in Russ.).

9. Zaprometov M.N. Osnovy biokhimii fenol'nykh soedinenii: uchebnoe posobie. [Fundamentals of Biochemistry of phenolic compounds, the manual]. Moscow, 1974, 214 p. (in Russ.).

10. Vysochina G.I. Rastitel'nye resursy, 1999, no 3, pp. 67-74. (in Russ.).

11. Artemkina N.A., Roshchin V.I. Rastitel'nye resursy, 2006, no. 3, pp. 66-73. (in Russ.). 